\title{
Incidence, Distribution, and Pathogenicity of Fungi Causing Root Rot in Idaho Long-Term Sugar Beet Storage Piles
}

Carl A. Strausbaugh, ${ }^{\dagger}$ United States Department of Agriculture-Agricultural Research Service Northwest Irrigation and Soils Research Laboratory, Kimberly, ID 83341

\begin{abstract}
Fungal rots in sugar beet roots held in long-term storage can lead to considerable sucrose loss but the incidence and distribution of fungal rots inside sugar beet piles and pathogenicity for some species is poorly understood. Thus, Idaho sugar beet held in five outdoor and two indoor piles in 2014 and 2015 were investigated. The root surface area covered by fungal growth and discolored and healthy tissue were assessed in nine $1-\mathrm{m}^{2}$ areas per pile using a stratified random sampling design. Pathogenicity was evaluated indoors via plug inoculation in 2015 and 2016. Botrytis cinerea covered more root surface area inside indoor piles (6 to $22 \%)$ than outdoor piles $(0$ to $3 \%)(P<0.0001)$. No trends were evident for the Athelia-like sp. (0 to $15 \%)$ and Penicillium-type spp. (0 to $8 \%)$. Penicillium-type isolates comprised the following species: $60 \%$ Penicillium expansum, $34 \%$ P. cellarum, $3 \%$ P. polonicum, and $3 \%$ Talaromyces rugulosus. Trace levels $(<1 \%$ of root surface) of other fungi,

including Cladosporium and Fusarium spp., were evident on roots and in isolations. Based on sample location in a pile, there were no trends or differences; however, two outdoor piles (OVP1 and OVP2) had more healthy tissue (90 to $96 \%)$ than other piles $(28$ to $80 \%)(P<0.0001)$. When the pathogenicity tests were analyzed by species, all were significantly different from each other $(P<0.0001)$, except for $P$. polonicum and P. expansum: B. cinerea $(61 \mathrm{~mm}$ of rot), $P$. polonicum $(36 \mathrm{~mm})$, P. expansum $(35 \mathrm{~mm})$, P. cellarum $(28 \mathrm{~mm})$, Athelia-like $\mathrm{sp} .(21 \mathrm{~mm})$, T. rugulosus $(0 \mathrm{~mm}$; not different from check), and noninoculated check $(0 \mathrm{~mm})$. The OVP1 and OVP2 piles had negligible fungal growth on roots after more than 120 days of storage under ambient conditions, which indicates that acceptable storage can be achieved over this time period through covering piles with tarps and cooling with ventilation pipe.
\end{abstract}

Maintaining sugar beet (Beta vulgaris L.) roots in long-term storage under ambient conditions can be a challenge while trying to sustain sucrose levels and limit losses to microbial colonization. In Idaho, when the sugar beet roots are harvested, they are delivered to the nearest piling ground. From the piling ground, approximately one-third of the crop is directly processed through the factory, while the remaining two-thirds of the roots are stored in piles $37 \mathrm{~m}$ wide at the base, $24 \mathrm{~m}$ wide at the top, and $8 \mathrm{~m}$ high (Peterson et al. 1984). Approximately half the roots in piles are held for 90 days or less, while the remaining roots may be stored until sometime in March or April (Huff 2013; Peterson et al. 1984). In Idaho, the outdoor piles held the longest are both ventilated and tarped (Bernhardson 2009; Peterson et al. 1984). When the current study was initiated in 2014, there were nine outdoor vent piles (OVP) and two indoor piles in Idaho that were in use for holding roots to the end of the storage season.

In the United States, sugar beet roots are stored under ambient conditions in Colorado, Idaho, Michigan, Montana, Nebraska, Oregon, and Wyoming, while roots stored in the Red River Valley of Minnesota and North Dakota are typically frozen in early December and

${ }^{\dagger}$ Corresponding author: Carl A. Strausbaugh;

E-mail: carl.strausbaugh@ars.usda.gov

Funding: These data support the objectives for the United States Department of Agriculture Current Research Information System project 2054-21220004-00D.

Mention of trade names or commercial products in this publication is solely for the purpose of providing scientific information and does not imply recommendation or endorsement by the U.S. Department of Agriculture. The USDA is an equal opportunity provider and employer.

*The $\boldsymbol{e}$-Xtra logo stands for "electronic extra" and indicates that one supplementary table is published online.

Accepted for publication 28 April 2018.

This article is in the public domain and not copyrightable. It may be freely reprinted with customary crediting of the source. The American Phytopathological Society, 2018. held frozen until they are processed (Bugbee 1993; Strausbaugh and Eujayl 2018; Strausbaugh et al. 2009, 2015). In recent years in Idaho, some roots harvested in October have been held for 150 or more days under ambient conditions until they were processed in late March and early April (Strausbaugh and Eujayl 2018). The roots stored long term under ambient conditions are subject to environmental fluctuations (both temperature and moisture) which can lead to both fungal and bacterial colonization and sucrose losses (Barr et al. 1940; Bugbee 1982, 1993; Campbell et al. 2011, 2014; Hansen 1949; Huijbregts et al. 2013; Kenter et al. 2006; Mumford and Wyse 1976; Strausbaugh et al. 2008b, 2011; Wyse 1978). Within a period of 1 month, the respiration rate will double when $20 \%$ of the sugar beet root surface is infected by Botrytis or Penicillium spp. (Mumford and Wyse 1976). In addition to losses to respiration, as sugar beet roots deteriorate, the ability to extract sucrose decreases as purity goes down (Bugbee 1993; Huijbregts et al. 2013; Kenter et al. 2006). Thus, millions of dollars can be lost annually when storing sugar beet roots under ambient conditions (Bugbee 1982; Bugbee and Cole 1976; Huff 2013; Van Driessche 2012). In 2004, the Michigan Sugar Company lost nearly \$25 million due to spoilage of sugar beet roots in storage piles (Van Driessche 2012).

Historically, the primary fungi associated with fungal root rots in stored sugar beet roots in the United States have been Botrytis cinerea Pers., Phoma betae A. B. Frank, and Penicillium vulpinum (Cooke \& Massee) Seifert \& Samson (syn. P. claviforme Bainer), although some studies mention Fusarium spp. as well (Bosch and Mirocha 1992; Bugbee 1975, 1982, 1993; Bugbee and Cole 1976; Bugbee and Nielsen 1978; Isaksson 1942; Mumford and Wyse 1976; Nihlgård et al. 2009). In recent Idaho studies conducted on the top of indoor piles, an Athelia-like sp., B. cinerea, and Penicillium spp. (primarily P. cellarum C. A. Strausb. \& Dugan and $P$. expansum Link.) were the predominant fungal species associated with both aerial mycelium and rotted tissue, while Phoma betae was also frequently associated with root lesions (Strausbaugh and Dugan 2017; Strausbaugh and Eujayl 2018; Strausbaugh et al. 2015; Toda et al. 2012). Based on data from four European countries (Belgium, Czech Republic, Germany, and Sweden), the primary pathogens common to all these areas were $B$. cinerea and Penicillium spp. The Netherlands also mentions Penicillium spp. as a dominant storage pathogen. However, the following fungi were also associated 
with storage rot in some of these European countries: Alternaria tenuis Nees, Aspergillus niger Tiegh., Cladosporium herbarum (Pers.) Link, Fusarium spp. (Fusarium cerealis (Cooke) Sacc., F. culmorum (Wm. G. Sm.) Sacc., F. graminearum Schwabe, and F. redolens Wollenw.), Monilia spp., Mucor hiemalis Wehmer, P. betae, Rhizoctonia violacea Kühn, Rhizopus nigricans Ehrenb., and Sclerotinia and Trichoderma spp. (Christ et al. 2011; Huijbregts et al. 2013; Liebe and Varrelmann 2016; Liebe et al. 2016). In Japan, B. cinerea, F. culmorum, Penicillium expansum, and Phoma betae were determined to be the primary fungal pathogens in storage (Uchino 2001). In Iran, the most pathogenic fungi associated with postharvest decay were Macrophomina phaseolina (Tassi) Goid., P. betae, Penicillium vulpinum, Phytophthora erythroseptica var. drechsleri (Tucker) Sarej. (syn. P. drechsleri Tucker), Rhizoctonia solani Kühn, and Rhizopus arrhizus A. Fisch. (Sheikholeslami et al. 1998). Fungi and Oomycota associated with rots in stored sugar beet roots that appear to be of lesser importance include Aspergillus fumigatus Fresen., Aphanomyces cochlioides Drechsler, Fusarium spp. (F. acuminatum Ellis \& Everh., F. avenaceum (Fr.) Sacc., F. equiseti (Corda) Sacc., F. moniliforme J. Sheld., F. oxysporum Schldtl., F. proliferatum (Matsush.) Nirenberg ex Gerlach \& Nirenberg, F. sambucinum Fuckel, F. solani (Mart.) Sacc., F. sporotrichioides Sherb., F. tricinctum (Corda) Sacc., and $F$. venenatum Nirenburg), Geotrichum spp., Gibellulopsis nigrescens (Pethybr.) Zare, W. Gams \& Summerb., Gliocladium spp., Neonectria ramulariae Wollenw., Penicillium spp. (P. cyclopium Westling, $P$. funiculosum Thom, $P$. paneum Frisvad, and $P$. verrucosum Dierckx), Phoma herbarum Westend., Pichia membranifaciens (E. C. Hansen) E. C. Hansen, Plectosphaerella cucumerina (Lindf.) W. Gams, Pythium spp. (Pythium dissotocum Drechsler, P. heterothallicum W. A. Campb. $\&$ F. F. Hendrix, P. intermedium de Bary, P. ultimum Trow, and P. vanterpoolii V. Kouyeas \& H. Kouyeas), Rhizopus stolonifer (Ehrenb.) Vuill., Sarocladium strictum (W. Gams) Summerb., and Trichoderma atroviride P. Karst. (Bosch and Mirocha 1992; Bugbee and Nielsen 1978; Christ et al. 2011; Halloin and Roberts 1995; Liebe and Varrelmann 2016; Liebe et al. 2016; Miles et al. 1977; Nihlgård et al. 2009; Sheikholeslami et al. 1998; Strausbaugh et al. 2015; Uchino 2001). Thus, the literature indicates that the mix of fungi associated with sugar beet root rot in storage may vary by region.

In efforts to alleviate losses to fungal rot in storage, host resistance and cultivar selection have been investigated; however, these alone have not been enough to limit losses (Bugbee 1993; Bugbee and Cole 1979; Strausbaugh et al. 2013). Currently, physical control practices such as tarping, ventilation, and stripping the outer meter of sugar beet roots from the pile surface are used to reduce sucrose losses (Bernhardson 2009; Bugbee 1993; Huijbregts et al. 2013; Peterson et al. 1980, 1984; Van Eerd et al. 2012). To supplement these physical control methods, chemical control measures have also been investigated but success has been limited (Bugbee and Cole 1979; Strausbaugh et al. 2015). Thiabendazole has been the only product labeled for sugar beet storage use in the past but has been only marginally effective in Idaho, and the current label no longer supports this use (Bugbee and Cole 1979; Strausbaugh et al. 2015). A recent study has shown the fungicides Propulse and Stadium to be affective for controlling fungal rots in Idaho but neither product is labeled for sugar beet storage use at this time (Strausbaugh et al. 2015). Some of the reluctance to label products for storage use stems from the lack of knowledge of market size because of the limited information available on the distribution of fungi in piles. Studies have identified the fungi associated with sugar beet roots in storage but only one previous study (Uchino 2001) has focused on the distribution of these fungi on or within storage piles. In Japan, a memoir describes the fungi associated with rot and their distribution on and within sugar beet storage piles (Uchino 2001). Therefore, given the millions of dollars in storage losses, the diversity of storage pile types, and the recent discovery of novel fungi (an Athelia-like sp. and P. cellarum) associated with stored rots in Idaho, there should be additional storage investigations (Huff 2013; Strausbaugh and Dugan 2017; Toda et al. 2012). Thus, studies were conducted to determine the pathogenicity, incidence, and distribution of the primary fungal root rots inside Idaho's long-term sugar beet storage piles. Knowledge gained from these data should allow for better sugar beet storage management options by better defining the market where chemical control will be needed and whether physical control methods may be adequate in some areas, given the right conditions.

\section{Materials and Methods}

2014 Pile sampling. A visual assessment of sugar beet roots in seven of the Amalgamated Sugar Company's nine long-term storage piles in Idaho was conducted on 12 to 13 March 2014. Two of the nine piles were not included in the study because of poor access and roots with field disease issues (high incidence of Aphanomyces root rot). Five of the seven piles included in the study were OVP designated by the following codes: OVP1 (1,325 $\mathrm{m}$ in elevation), OVP2 (1,324 m), OVP3 (1,273 m), OVP4 (1,308 m), and OVP5 (1,168 m) (for exact pile locations and names, contact the Amalgamated Sugar Co. LLC, Boise, ID). The remaining two piles were indoor building piles (IBP) designated as IBP1 (1,266 m) and IBP2 (1,266 m). The roots in the seven piles at the time of piling in October were healthy in appearance, because less than $1 \%$ of the roots had any evidence of field disease issues based on a visual assessment of the sides of the piles. The two indoor building piles had a temperature set point (target temperature) of $1.1^{\circ} \mathrm{C}$. The roots in the buildings were cooled using ambient air forced up through the floor, which allowed the set point to be reached on 13 November (Strausbaugh and Eujayl 2018). The buildings lack supplemental cooling. Thus, if ambient air temperatures were too warm, the buildings would struggle to both reach the set point and maintain it (the same is true for OVP). The humidity in the buildings was not controlled but the humidity remained above $90 \%$ when measured at the top of the pile (Strausbaugh et al. 2015). The other five piles were all outdoor piles cooled (same set point as indoor piles) with $0.9-\mathrm{m}$-diameter pipes placed on $3.7-\mathrm{m}$ centers throughout the bottom of the pile. The OVP were covered with tarps (Bernhardson 2009) until 1 to 2 weeks prior to initiating reloading of the roots back into trucks for delivery to the factory. At the time of data collection, the reloading process had progressed to where at least the first $50 \mathrm{~m}$ of the pile had been reloaded. Data for fungal distribution in the piles were collected using a stratified random sampling design (Delp et al. 1986), with nine blocks in a three-by-three grid on the recently exposed pile end. Within each block, a $1-\mathrm{m}^{2}$ PVC frame was arbitrarily placed with the aid of a JCB 520 Loadall telehandler (forklift with a telescopic arm; J. C. Bamford Excavators Ltd., Rochester, Staffordshire, England). The exposed face of the roots that were completely within this area was visually assessed for the percentage fungal growth, discolored tissue, and healthy appearing tissue. For the percentage of fungal growth on the root surface, each fungal type (fungal growth appearance, presumably representing a single fungal species) evident was assessed independently. Fungal types covering less than $1 \%$ of the root surface were not included in the data collection. An isolation from both aerial mycelium and the associated root lesion (isolated from where rotted tissue meets healthy tissue) for each visually assessed fungal type in every block was conducted on potato dextrose agar (PDA; Becton Dickinson \& Co., Sparks, MD) with streptomycin (200 mg/liter) and incubated on the laboratory bench at $22^{\circ} \mathrm{C}$ using methods described previously (Strausbaugh et al. 2015). To determine whether location within a pile was important, the samples from within the grid pattern were compared in three ways. In the sides-to-middle comparison, the six samples collected closer to the sides were compared versus the three samples from the middle section. In the vertical position comparison, the three samples collected near the top of the piles was compared versus the middle three samples and the bottom three samples. In the outside-inside comparison, the seven samples collected from the outer portion of the pile were compared with the two collected from the inner portion of the pile.

2015 Pile sampling. A visual assessment of sugar beet roots in long-term storage piles was conducted on 3 to 5 March 2015 at the same seven piles evaluated in 2014. The roots in the seven piles at the time of piling in October were healthy in appearance, because less than $1 \%$ of the roots had any evidence of field disease issues based on a visual assessment of the sides of the piles. The temperature set point 
in the indoor buildings was reached on 22 November (Strausbaugh and Eujayl 2018). All methods for the 2015 pile sampling were the same as those described for the 2014 sampling.

Fungal identification. Both micro- and macromorphological characteristics of single-spore or hyphal-tipped cultures (Nelson et al. 1983) on PDA at $22^{\circ} \mathrm{C}$ were used as the basis for identification to genus or species. Isolates ( 7,8 , and 35 isolates for the Athelia-like sp., Botrytis sp., and Penicillium-type spp., respectively) were arbitrarily selected to confirm the morphological identifications through the sequencing of DNA regions. A larger subset of Penicillium-type isolates was selected because there were multiple species present among the isolates based on morphology, whereas other fungal types represented only a single species. The internal transcribed spacer$5.8 \mathrm{~S}$ (ITS), $\beta$-tubulin (TUB2), RNA polymerase II second largest subunit (RPB2), and calmodulin (CMD) DNA regions were sequenced for the Penicillium-type isolates to confirm species identity (Visagie et al. 2014). For the Botrytis sp. isolates, the ITS, RPB2, glyceraldehyde-3-phosphate dehydrogenase (G3PDH), and heatshock protein 60 (HSP60) DNA regions were sequenced (Staats et al. 2005). For the Athelia-like sp. isolates, the ITS and the $28 \mathrm{~S}$ ribosomal RNA (28S) DNA regions were sequenced (Toda et al. 2012). To support future identification and comparisons, the CMD, G3PDH, and 28S DNA regions for $P$. cellarum and the G3PDH and RPB2 DNA regions for the Athelia-like isolates were also sequenced. DNA for the isolates was prepared by growing the isolates in potato dextrose broth (PDB; Becton Dickinson \& Co.) and extracting the DNA with a DNeasy Plant Mini Isolation Kit (Qiagen Inc., Valencia, CA) using methods described previously (Strausbaugh et al. 2015). The DNA was stored at $-20^{\circ} \mathrm{C}$ in Buffer $\mathrm{AE}$ from the isolation kit. The polymerase chain reaction (PCR) assays were performed in volumes of $30 \mu \mathrm{l}$ with GoTaq Taq DNA polymerase (Promega Corp., Madison, WI) along with primers (except for CMD) and methods described previously (Strausbaugh et al. 2015). The CMD primers were CMD5 5'-CCGAGTACAAGGARGCCTTC-3' and CMD6 5'CCGATRGAGGTCATRACGTGG-3' (Hong et al. 2006). For Sanger sequencing, the amplicons were sent to TACGen (Richmond, CA) for PCR cleanup to remove excess dNTP and unincorporated primers, and sequencing in both directions. Sequences were evaluated using BioEdit version 7.1.3.0 (Hall 1999) and CLC Main Workbench Ver. 7.9.1 (Qiagen Inc.), consensus sequences were generated, and representative haplotypes were submitted to GenBank (accessions MG714818 to MG714869; Supplementary Table S1). The sequences were compared with accessions in GenBank to confirm species identity using BLASTN 2.7.1 (Altschul et al. 1997). The GenBank accessions for the species of interest and closely related species were compared with the sequences from the current study in phylogenetic analyses using concatenated datasets. The DNA sequences were aligned using ClustralX, version 2.0 (Larkin et al. 2007). MEGA7, version 7.0.26 (Kumar et al. 2016), was used to determine the substitution model that best fit the data according to the Bayesian Information Criterion. MEGA7 was also used to conduct the maximum-likelihood analyses, with an initial search (two replicates) used to estimate the model parameters. The parameters were then fixed for a bootstrap analysis of 1,000 replicates. The maximum-parsimony analyses were performed using PAUP, version 4.0b10 (Swofford 2002), with the heuristic search, simple taxon addition sequences, tree bisectionreconnection branch swapping, and MaxTrees $=100$. Statistical support for the analyses was determined by bootstrap values for 1,000 replicates. MrBayes, version 3.2.6 (Ronquist and Huelsenbeck 2003), was used to conduct the Bayesian phylogenetic analyses, with the searches run until the standard deviation of split frequencies fell below 0.01 . The analyses were conducted using the default priors. The majority-rule consensus was then calculated after removing the first $25 \%$ of generations as burn-in. The phylogenetic trees were visualized using FigTree, version 1.4.3 (Rambaut 2016).

Pathogenicity tests. Thirty isolates from the three main fungal types obtained from rot lesions on sugar beet roots in Idaho storages were compared for their ability to cause rot in sugar beet roots. Roots for the study were obtained from the commercial sugar beet cultivar B7 (for uncoded cultivar name, contact Betaseed Inc., Kimberly, ID), which had been produced according to the 2015 Amalgamated grower guide (Amalgamated Sugar Co. LLC, Boise, ID) in a Kimberly, ID field $\left(42^{\circ} 33^{\prime} 10.37^{\prime \prime} \mathrm{N}, 114^{\circ} 21^{\prime} 25.22^{\prime \prime} \mathrm{W}\right.$, elevation 1,187 $\mathrm{m})$. The roots harvested on 7 October 2015 were all healthy in appearance and held inside a wooden onion box (1.2 by 1.8 by $0.8 \mathrm{~m}$; Boise River Pack, Notus, ID) which was placed inside the North commercial sugar beet storage building in Paul, ID (temperature set point $1.1{ }^{\circ} \mathrm{C}$; cooled using ambient air; $>90 \%$ relative humidity). The temperature was recorded on 1-h intervals using $\mathrm{HOBO}$ sensors (model H08-001-02; Onset Computer Corp., Bourne, MA). On 2 November, the roots were each inoculated with one of 31 treatments: a noninoculated check or one of 30 fungal isolates $(5 \mathrm{~B} . \mathrm{cin}$ erea, 5 Athelia-like, $10 P$. cellarum, $8 P$. expansum, $1 P$. polonicum, and 1 T. rugulosus) selected arbitrarily. The treatments (a single root was an experimental unit) were arranged in a randomized complete block design with six replications in the bottom of onion boxes. The roots were inoculated by placing an 8-mm-diameter PDA plug into a 24-mm-deep hole created on the shoulder of the root with a 10-mm-diameter cork borer (the outside of the root was not sterilized). Plugs for the noninoculated check came from a PDA plug with no fungus, while the plugs for the fungal treatments came from 2week-old cultures grown on PDA at $22^{\circ} \mathrm{C}$ in the dark. The root plug pulled by the cork borer was replaced after the PDA plug inoculation and sealed with petroleum jelly (UNILIVER, Greenwich, CT). After 101 days in storage, on 10 February 2016, the roots were bisected through the inoculation plug and the diameter of the rot was measured with a ruler. Reisolations were conducted from 30 inoculation sites (10 isolations per fungal type) and the noninoculated checks. Reisolations were conducted by taking an approximately 40-by-40$\mathrm{mm}$ piece of tissue from the leading edge of the discolored tissue (edge of plug for checks) and placing a 2-by-2-mm portion of that tissue onto PDA amended with streptomycin $(200 \mathrm{mg} / \mathrm{liter})$ using methods described previously (Strausbaugh et al. 2015). The test was repeated in 2016 with the same isolates and methods. The 2016 roots were harvested on 11 October, inoculated on 27 October, and evaluated after 106 days in storage, on 9 February 2017.

Data analysis. The SAS (version 9.4; SAS Institute Inc., Cary, NC) Univariate procedure was used to test for normality. Levene's test was used to determine homogeneity of variance. Analysis of variance for pile data were performed using the SAS generalized linear models procedure (Proc GLM). Mean comparisons were conducted using Fisher's protected least significant difference $(\alpha=0.05)$. Pathogenicity data were evaluated through analysis of variance using the SAS generalized linear mixed-models procedure (Proc GLIMMIX). In the model statement, the fixed effects were experiment and isolate or species. The random effects were block and any interaction terms with block. In the model statement, the denominator degrees of freedom were calculated using the DDFM = KENWARDRODGER option. Mean comparisons were conducted using least square means $(\alpha=0.05)$ while using the "Lines" output option. Community data analysis was conducted in R, version 3.4.2 (R Core Team 2017), with the Community Ecology package "vegan", version 2.4-4 (Oksanen et al. 2017). The Bray-Curtis dissimilarity matrix was calculated with vegan. To partition the variation within each distance matrix, nonparametric permutational multivariate analysis of variance (PERMANOVA) was performed using the vegan function Adonis2 (permutations $=999$ ). Homogeneity of group dispersions was tested via the vegan function betadisper. Significance values were obtained by permutation $(n=999)$. To visualize differences in fungal community structure among piles and corroborate the results of the PERMANOVA, a nonmetric multidimensional scaling (NMDS) of each distance matrix was performed with the function metaMDS in vegan (maximum permutations $=999$ ) with default settings. The goodnessof-fit for variables was evaluated using the command envfit. Groups were considered significantly different for $\alpha=0.05$ if the $95 \%$ confidence regions did not overlap.

\section{Results}

Fungal incidence and root appearance. In 2014 and 2015, the average number of roots assessed per square meter was $23 \pm 3$ and 
$30 \pm 1$, respectively. The analysis of variance by years differed for all variables $(P=0.004$ to $P<0.0001)$, except for discolored tissue $(P=0.9602)$. However, homogeneity of variance between years for discolored tissue was significantly different $(P=0.0375)$. Thus, data were presented by year in Table 1, with significant differences $(P<0.0001)$ observed in both years for all variables. In both years, the OVP1 and OVP2 piling grounds had more $(P<0.0001)$ heathy tissue ( 90 to $96 \%$ ) and less fungal growth (1 to $2 \%$ ) on the root surface than the roots at other piling grounds (Table 1). These two piles also had less discolored tissue $(1$ to $8 \% ; P<0.0001)$. However, with 2014 roots, OVP1 was not different from OVP3. On the other hand, OVP4 was among the piles with more discolored (32 to 56\%) tissue in both years but was only intermediate for fungal growth (9 to 15\%). In both years, the IBP2 pile had the most surface fungal growth (16 to $44 \%$ ). The surface fungal growth at all piles was dominated by three fungal types (Athelia-like sp., B. cinerea, and Penicillium-type spp.) in both years (Table 1). Other fungal types such as Cladosporium and Fusarium spp. were only present at trace levels (covered less than $1 \%$ of the root surface); therefore, they were difficult to assess and not included in the data analysis in Table 1 . In both years, the two indoor piles (IBP1 and IBP2) had more $(P<0.0001) B$. cinerea on the root surface (6 to 22\%) than the other piles. All of the outdoor piles had only 0 to $3 \% \mathrm{~B}$. cinerea on the root surface in both years. The pile with the most Athelia-like fungus ( 9 to $15 \%$ ) varied between years but the OVP1 and OVP2 piles had less of this fungus ( 0 to $2 \%$ ) in both years, based on ranking. The Penicillium-type fungi only covered from 0 to $1 \%$ of the root surface regardless of pile in 2015 but covered up to $8 \%$ of the root surface in three 2014 piles. When combining all three fungal types in a multivariate analysis, PERMANOVA also suggested that there were differences between piles in both years $(P<0.001)$. However, the homogeneity of multivariate dispersions was also significant $(P=0.01)$ in both years, making decisions based on this analysis problematic. Differences among piles in both years was also supported by NMDS ordination plots with 95\% confidence regions (Fig. 1). In both years the piles fell in the same general three groups on the plot. One group was formed by the OVP1 and OVP2 piles, which supports fungal and tissue results mentioned earlier in this section. The two IBP formed a second group, while the remaining OVP formed a third group.
Distribution of fungal growth and tissue appearance in piles. There was a lack of trends or differences $(P=0.4880$ to 0.9646$)$ for any of the variables when comparing samples collected from different positions in the piles based on vertical positioning (top, middle, and bottom; Table 2). When comparing samples from the sides versus the middle $(P=0.1626$ to 0.9356$)$ and inside versus outside $(P=0.1097$ to 0.9929$)$, no differences were evident (data not shown). With 2014 and 2015 roots (Table 3), the indoor piles (38 and $14 \%$, respectively) had more $(P<0.0001)$ fungal growth than the outdoor piles (11 and 6\%, respectively). With 2014 and 2015 roots (Table 3$)$, there was also more $(P=0.0333$ to 0.0005$)$ healthy tissue associated with roots in outdoor piles (68 and 74\%, respectively), whereas the indoor piles had less (43 and 63\%, respectively). Also, in both years, there was more $(P<0.0001) B$. cinerea on the root surface with indoor piles ( 8 to $18 \%$ indoors and 0 to $2 \%$ outdoors), whereas there were no consistent trends with the other two fungal types (Table 3). Differences between pile types based on tissue discoloration were not evident $(P=0.4598$ to 0.7500 ; Table 3$)$.

Fungal isolations from pile roots. In 2014, 132 isolations were conducted to confirm the fungus associated with the aerial mycelium and under lying root lesion for each fungal type. All 2014 isolations for $B$. cinerea and the Penicillium-type fungi were confirmed. The 2014 Athelia-like isolations were confirmed in $45 \%$ of the samples. In 2015,100 isolations were conducted to confirm the fungus associated with each fungal type. All 2015 isolations for B. cinerea and the Penicillium-type fungi were confirmed. The 2015 Athelia-like isolations were confirmed in $86 \%$ of the samples.

Fungal sequencing. For sequenced isolates, the fungi identified based on macro- and micromorphology were confirmed. For the 35 Penicillium-type isolates selected arbitrarily to be sequenced, the following fungi were identified: P. expansum (60\% of samples), P. cellarum (34\%), P. polonicum K. W. Zalessky (3\%), and Talaromyces rugulosus (Thom) Samson, N. Yilmaz, Frisvad \& Seifert (3\%). The identification of the $21 P$. expansum isolates established via macroand micromorphology was also supported by BLASTN search results. For ITS, the $P$. expansum isolates had $100 \%$ sequence identity with the P. expansum type strain CBS325.48 (GenBank accession AY373912) and ex-neotype strain ATCC7861 (NR_077154). For BenA, P. expansum isolates (F758, F771, and F777) had 99 to

Table 1. Percentage of root surface covered by fungi and discolored tissue in sugar beet storage piles in Idaho during the 2014-15 and 2015-16 storage seasons ${ }^{\mathrm{y}}$

\begin{tabular}{|c|c|c|c|c|c|c|}
\hline Piles $^{z}$ & Athelia-like & Botrytis cinerea & Penicillium-type & Fungi & Discolored & Healthy \\
\hline \multicolumn{7}{|l|}{ 2014-15 } \\
\hline OVP2 & $1 \mathrm{~b}$ & $1 \mathrm{c}$ & $1 \mathrm{c}$ & $2 \mathrm{e}$ & $1 \mathrm{e}$ & $96 \mathrm{a}$ \\
\hline OVP1 & $0 \mathrm{~b}$ & $0 \mathrm{c}$ & $1 \mathrm{c}$ & $1 \mathrm{e}$ & $8 d$ & $90 \mathrm{a}$ \\
\hline OVP3 & $5 \mathrm{~b}$ & $3 \mathrm{c}$ & $3 b$ & $10 \mathrm{~d}$ & $10 \mathrm{~d}$ & $80 \mathrm{~b}$ \\
\hline IBP1 & $12 \mathrm{a}$ & $15 \mathrm{~b}$ & $4 \mathrm{~b}$ & $31 \mathrm{~b}$ & $19 \mathrm{c}$ & $50 \mathrm{c}$ \\
\hline OVP5 & $14 \mathrm{a}$ & $3 c$ & $8 \mathrm{a}$ & $24 \mathrm{c}$ & $30 \mathrm{~b}$ & $46 \mathrm{c}$ \\
\hline IBP2 & $15 \mathrm{a}$ & $22 \mathrm{a}$ & $8 \mathrm{a}$ & $44 \mathrm{a}$ & $20 \mathrm{c}$ & $35 \mathrm{~d}$ \\
\hline OVP4 & $5 \mathrm{~b}$ & $3 c$ & $8 \mathrm{a}$ & $15 \mathrm{~d}$ & $56 \mathrm{a}$ & $28 \mathrm{~d}$ \\
\hline$P$ value & $<0.0001$ & $<0.0001$ & $<0.0001$ & $<0.0001$ & $<0.0001$ & $<0.0001$ \\
\hline $\operatorname{LSD}(\alpha=0.05)$ & 5 & 5 & 2 & 6 & 7 & 8 \\
\hline \multicolumn{7}{|l|}{ 2015-16 } \\
\hline OVP2 & $1 \mathrm{~d}$ & $0 \mathrm{c}$ & $1 \mathrm{a}$ & $1 \mathrm{c}$ & $7 \mathrm{~d}$ & $92 \mathrm{a}$ \\
\hline OVP1 & $2 \mathrm{~cd}$ & $0 \mathrm{c}$ & $0 \mathrm{~b}$ & $2 \mathrm{c}$ & $6 \mathrm{~d}$ & $92 \mathrm{a}$ \\
\hline OVP5 & $9 \mathrm{a}$ & $1 \mathrm{c}$ & $1 \mathrm{a}$ & $11 \mathrm{~b}$ & $19 \mathrm{c}$ & $70 \mathrm{~b}$ \\
\hline IBP1 & $4 \mathrm{bc}$ & $6 \mathrm{~b}$ & $1 \mathrm{a}$ & $11 \mathrm{~b}$ & $25 \mathrm{bc}$ & $64 \mathrm{bc}$ \\
\hline IBP2 & $5 \mathrm{~b}$ & $11 \mathrm{a}$ & $1 \mathrm{a}$ & $16 \mathrm{a}$ & $21 \mathrm{c}$ & $62 \mathrm{bc}$ \\
\hline OVP4 & $8 \mathrm{a}$ & $1 \mathrm{c}$ & $1 \mathrm{a}$ & $9 \mathrm{~b}$ & $32 a b$ & $58 \mathrm{c}$ \\
\hline OVP3 & $8 \mathrm{a}$ & $0 \mathrm{c}$ & $0 \mathrm{~b}$ & $8 \mathrm{~b}$ & $36 a$ & $56 \mathrm{c}$ \\
\hline$P$ value & $<0.0001$ & $<0.0001$ & 0.0019 & $<0.0001$ & $<0.0001$ & $<0.0001$ \\
\hline $\operatorname{LSD}(\alpha=0.05)$ & 3 & 2 & 1 & 4 & 9 & 10 \\
\hline
\end{tabular}

y The Athelia-like sp. is a basidiomycete described previously (Toda et al. 2012). The Penicillium-type spp. were primarily Penicillium expansum and P. cellarum. Fungi $=$ percentage root surface area covered by fungus. Discolored $=$ percentage of root surface discolored but not covered by fungus. Healthy $=$ percentage of root surface area healthy in appearance.

${ }^{\mathrm{z}} \mathrm{OVP}=$ outdoor vent pile and IBP $=$ indoor building pile. $P$ value was the probability associated with the $F$ value. Within a column by year, the means followed by the same letter did not differ significantly based on Fisher's protected least significant difference (LSD; $\alpha=0.05)$. Homogeneity of variance was not met for the Athelia-like sp. and B. cinerea in both years and fungi and healthy in 2014. However, the problem appeared to be related to differences in magnitude; therefore, analysis of variance was still conducted. 
$100 \%$ sequence identity with $P$. expansum type strain CBS325.48 (JQ965099 and AY674400). For RPB2, P. expansum isolates (F758, F778, F779, F788, and F794) had 99 to $100 \%$ sequence identity with $P$. expansum type strain CBS325.48 (JF417427) and MD-8 (XM_016739629; strain used for the National Center for Biotechnology Information P. expansum genome project). For CMD, P. expansum isolates (F758, F788, F791, and F797) had 99\% sequence identity with $P$. expansum strains CBS325.48 (DQ911134) and AS3.6631 (AY678567). Based on morphology and BLASTN search results, the Penicillium spp. most closely related to the isolates was established and utilized to examine the evolutionary relationship of the isolates. Evolutionary relationships support the morphology
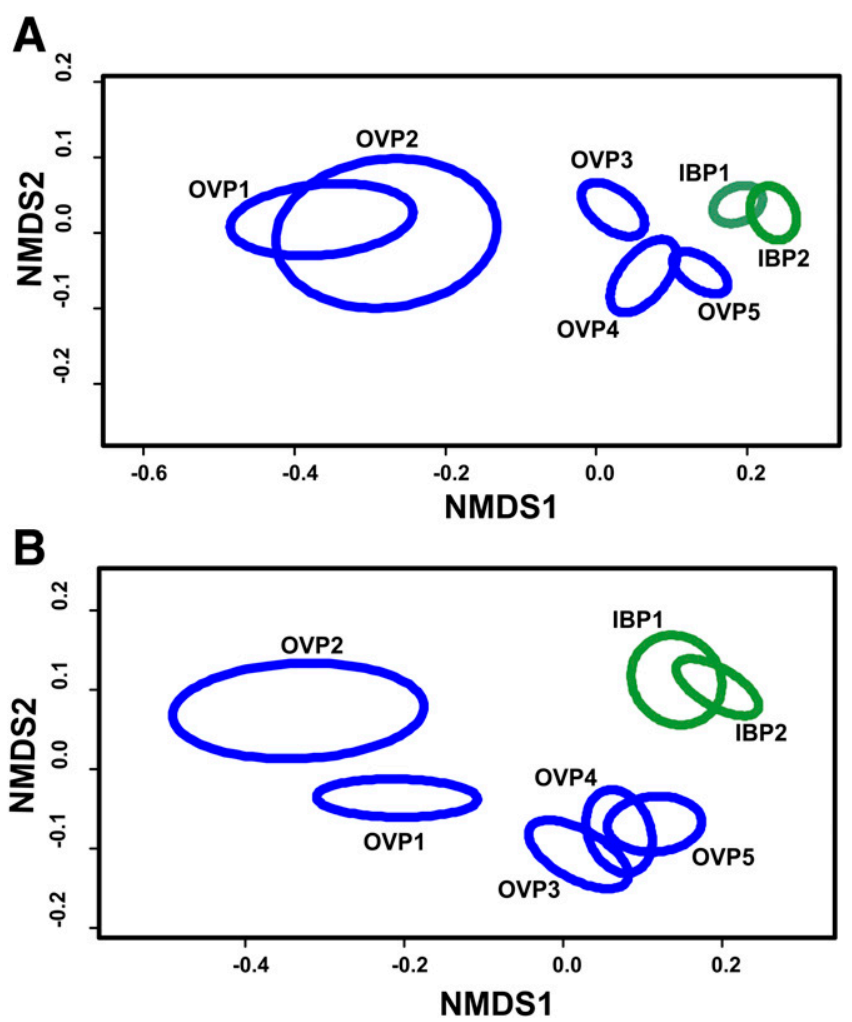

Fig. 1. Nonmetric multidimensional scaling (NMDS) plot for seven Idaho sugar beet piles (outdoor vent piles [OVP] $=$ blue and indoor building piles $[\mathrm{IBP}]=$ green) in $\mathbf{A}$, 2014 (stress $=0.07$ ) and $\mathbf{B}, 2015$ (stress $=0.09$ ) based on the percentage of root surface covered by fungal growth inside the piles. Three primary fungal types (Athelia-like sp., Botrytis cinerea, and Penicillium-type spp.) found on the root surface were evaluated together to establish an ellipsoid ( $95 \%$ confidence region) for each pile. and BLASTN results by establishing that the $21 P$. expansum isolates were most closely related to the $P$. expansum type strain CBS325.48 (Fig. 2). The identification of the $12 P$. cellarum isolates established via macro- and micromorphology was also supported by BLASTN search results. For ITS and BenA, the $P$. cellarum isolates had $100 \%$ sequence identity with the $P$. cellarum ex-type strain NRRL66633 (KM249068 and KM249108, respectively; also referred to as strain F727). For RPB2, the $P$. cellarum isolates had 99 to $100 \%$ sequence identity with the $P$. cellarum ex-type strain NRRL66633 (KM249117). For CMD, the $P$. cellarum isolates had 99\% sequence identity with $P$. cellarum ex-type strain NRRL66633 (MG714820). The evolutionary relationships in Figure 2 also confirm that the $12 P$. cellarum isolates were closely related to the type strain for this species. To support future identification and comparisons with the $P$. cellarum ex-type strain NRRL66633, sequencing for CMD (MG714820), G3PDH (MG714829), and 28S (MG714818) was also submitted to GenBank. The identification of the P. polonicum isolate established via macro- and micromorphology was also supported by BLASTN search results. The $P$. polonicum isolate F775 had 99 to $100 \%$ sequence identity with $P$. polonicum strains (ITS: AF033475 and NR_103687; BenA: KY172966, LT559044, and EU128556; RPB2: JN406609 and JN985414; and CMD: KU896848). The evolutionary relationships in Figure 2 also confirm that the $P$. polonicum isolate was closely related to the type strain for this species. The identification of the T. rugulosus isolate established via macro- and micromorphology was also supported by BLASTN search results. The $T$. rugulosus isolate had high sequence identity with the following T. rugulosus strains: $99 \%$ identity for ITS with CBS 371.48 (KF984834), DTO 249C9 (KC797646), F729 (KM249069), NRRL1045 (KF196902), and PM10 (KJ744357); 98\% identity for BenA with DTO129A1 (KJ775189), DTO180B9 (KF984570), DTO193I5 (KF984578), DTO199H3 (KF984576), and DTO269G1 (KF984581); and 100\% identity for CMD with DTO14A2 (JX140718 and KF984703) and DTO63C7 (JX140721).

The identification of the $B$. cinerea isolates established via macroand micromorphology was also supported by BLASTN search results. The $B$. cinerea isolates that were sequenced also had close relationships with established $B$. cinerea strains via BLASTN. The $B$. cinerea isolates had 99 to $100 \%$ sequence identity with previously established B. cinerea strains: ITS (CP009808, KJ937044, and KJ937046), RPB2 (CP009818, KX266744, KM249120, and JN692416), G3PDH (CP009819, JN692403, JN692409, and KJ937074), and HSP60 (JN692388, JN692389, and KJ937066). These results were also supported by all eight $B$. cinerea isolates having close evolutionary relationships with established $B$. cinerea strains (Fig. 3). The identification of the Athelia-like sp. isolates established via macro- and micromorphology was also supported by BLASTN search results. The Athelia-like sp. isolates had 99 to $100 \%$ sequence identity with previously established Athelia-like

Table 2. Percentage of root surface covered by fungi and discolored tissue depending on sample position (top, middle, and bottom) in sugar beet storage piles in Idaho during the 2014-15 and 2015-16 storage seasons ${ }^{\mathrm{y}}$

\begin{tabular}{|c|c|c|c|c|c|c|}
\hline Position $^{z}$ & Athelia-like & Botrytis cinerea & Penicillium-type & Fungi & Discolored & Healthy \\
\hline \multicolumn{7}{|l|}{$2014-15$} \\
\hline Top & 8 & 6 & 4 & 18 & 19 & 62 \\
\hline Middle & 7 & 7 & 4 & 18 & 18 & 63 \\
\hline Bottom & 7 & 7 & 4 & 18 & 25 & 57 \\
\hline$P$ value & 0.8214 & 0.9646 & 0.9897 & 0.9884 & 0.4880 & 0.7330 \\
\hline \multicolumn{7}{|l|}{$2015-16$} \\
\hline Top & 6 & 3 & 1 & 9 & 20 & 71 \\
\hline Middle & 5 & 3 & 1 & 9 & 22 & 70 \\
\hline Bottom & 5 & 3 & 1 & 8 & 20 & 71 \\
\hline$P$ value & 0.7368 & 0.9447 & 0.6368 & 0.8517 & 0.9119 & 0.9288 \\
\hline
\end{tabular}

${ }^{\mathrm{y}}$ The three samples collected near the top of the piles were compared versus the middle three samples and the bottom three samples across all the piles. The Athelia-like sp. is a basidiomycete described previously (Toda et al. 2012). The Penicillium-type spp. were primarily Penicillium expansum and P. cellarum. Fungi $=$ percentage root surface area covered by fungus. Discolored $=$ percentage of root surface discolored but not covered by fungus. Healthy $=$ percentage of root surface area healthy in appearance.

${ }^{\mathrm{z}} P$ value was the probability associated with the $F$ value. 
sp. strains: ITS (AB596010, AB596012, AB596067, and KM249067) and large subunit (AB596026). The evolutionary relationships in Figures 4 and 5 also suggest that the seven Athelia-like sp. isolates were closely related to previously established Athelia-like sp. strains from sugar beet (Strausbaugh et al. 2015; Toda et al. 2012) along with two strains from other studies (SM1 and BF OTU147). The Athelialike sp. isolates were most closely related to the Athelia bombacina strains (Figs. 4 and 5). To support future identification and naming of these Athelia-like isolates, sequencing for G3PDH (MG714832 to MG714835) and RPB2 (MG714859 to MG714863) was also submitted to GenBank.

Pathogenicity tests. The temperature profiles for the roots in storage in both years are shown in Figure 6. The 2015 and 2016 pathogenicity tests were significantly different $(P=0.0346)$ when analyzed by isolate (Table 4 ); therefore, the data for these 2 years were considered separately. In both years, all isolates were pathogenic (significantly different from the noninoculated check), except for $T$. rugulosus (Table 4). In both years, all B. cinerea isolates were more virulent than all other isolates (Table 4). With isolates other than $B$. cinerea and $T$. rugulosus, a continuum of virulence was evident with the $P$. expansum and $P$. polonicum isolates at the more virulent end of the continuum and the Athelia-like isolates at the less virulent end (Table 4). When analyzed by species, the 2015 and 2016 pathogenicity tests were not significantly different $(P=$ $0.1025)$ and the variances were homogeneous $(P=0.1843)$; therefore, the two experiments were considered together. Except for $P$. polonicum and $P$. expansum, the species were all significantly different from each other $(P<0.0001)$, with the following levels of rot: B. cinerea $(61 \mathrm{~mm}), P$. polonicum $(36 \mathrm{~mm}), P$. expansum $(35 \mathrm{~mm})$, P. cellarum $(28 \mathrm{~mm})$, Athelia-like $\mathrm{sp} .(21 \mathrm{~mm})$, T. rugulosus $(0 \mathrm{~mm}$ [not different from the check]), and noninoculated check $(0 \mathrm{~mm})$. For both pathogenicity tests, all isolations from root lesions for the B. cinerea (10 isolations per study; 20 total) and Penicillium-type (10 isolations per study; 20 total) isolates were successful at obtaining the same fungus. The Athelia-like isolations (10 isolations per study; 20 total) were only $50 \%$ successful in both years because contaminants over grew the material. No fungi were associated with tissue from the noninoculated checks.

\section{Discussion}

Incidence, distribution, and pathogenicity were established for the three primary fungal genera (Athelia-like sp., B. cinerea, and Penicillium spp.) associated with both mycelium on the root surface and the underlying rotted tissue in long-term Idaho storage piles. No trends in the incidence of fungal types were evident with outdoor piles but, in both years, $B$. cinerea was the most prevalent fungus from the two indoor piles. The two indoor piles also had more total fungal surface growth compared with the outdoor piles, which was consistent with observations from previous indoor studies with high humidity (Isaksson 1942; Strausbaugh et al. 2015). The fungal incidence for all fungal types did not vary with location within the piles. The $B$. cinerea isolates were the most virulent in both years in pathogenicity tests.
Penicillium spp. were the next most virulent fungi isolated, while decreasing in virulence in the following order: $P$. polonicum, $P$. expansum, and $P$. cellarum. The Athelia-like sp. isolates were also pathogenic, whereas the $T$. rugulosus isolate was nonpathogenic. The current study represents the first time the virulence of the novel Athelia-like sp. and $P$. cellarum were compared side by side with the other primary sugar beet storage pathogens from Idaho. The spatial distribution of fungi in long-term sugar beet storage piles both indoors and outdoors and on the root surface also had not been directly investigated previously in the United States.

Root surface coverage and distribution of fungi within both indoor and outdoor piles was the focus of the current study, whereas most previous studies worldwide had focused on fungal incidence associated with rot lesions (Bugbee 1993; Christ et al. 2011; Huijbregts et al. 2013; Liebe and Varrelmann 2016; Miles et al. 1977; Nihlgård et al. 2009; Sheikholeslami et al. 1998), except for an investigation in Japan (Uchino 2001). In Idaho, with sugar beet roots harvested in October and assessed in early March (at least 120 days in storage), the 2014 root surface area covered by fungi ranged from 1 to $44 \%$ depending on pile, while 2015 roots ranged from 1 to $16 \%$ with the same three primary fungal types (Athelia-like, Botrytis, and Penicillium-type) in both years. The dominant fungus on roots in the indoor piles was $B$. cinerea, which is similar to what was observed in the spring of 1941 in Colorado root cellars (Isaksson 1942). No obvious trends were apparent with the other fungal genera.

The six variables assessed in the current study did not vary with location within piles. An investigation in Japan that focused on long-term storage in outdoor sugar beet piles found Botrytis, Penicillium, and Fusarium spp. to be the primary fungal types and also found no difference in their distribution within piles (Uchino 2001). The dry surface on the sides of the piles in Japan were favored by Cladosporium spp., while the humid surface at the top of the pile was favored by Geotrichum spp. (Uchino 2001). Only roots inside the piles were investigated in the current study but a recent Idaho investigation (Strausbaugh et al. 2015) conducted on the surface of the pile in the North indoor building identified the same three fungal types as were found inside the pile in the current study. A comprehensive study of the root surface on the sides and top of outdoor piles in Idaho has not been conducted.

When sugar beet roots were inoculated with isolates from the three fungal types and held in the indoor storage building, five fungal species were determined to be pathogenic (ordered from most virulent to least virulent): $B$. cinerea, $P$. polonicum, $P$. expansum, $P$. cellarum, and the Athelia-like sp. In previous controlled-temperature studies, $P$. vulpinum has also been determined to be less virulent than $P$. betae and B. cinerea (Bugbee 1975). Bugbee mentions that $B$. cinerea is the most destructive storage pathogen worldwide but, in the Red River Valley production area in the United States, $P$. betae and $P$. vulpinum were more frequently isolated (Bugbee 1982, 1993). In Japan, $B$. cinerea also caused the largest root lesions, while $F$. culmorum, $P$. expansum, and $P$. betae were also capable of causing rot (Uchino 2001). Idaho-related studies have been the only studies to

Table 3. Percentage of root surface covered by fungi and discolored tissue depending on pile type (indoors versus outdoors) in sugar beet storage piles in Idaho during the 2014-15 and 2015-16 storage seasons ${ }^{y}$

\begin{tabular}{|c|c|c|c|c|c|c|}
\hline Position $^{z}$ & Athelia-like & Botrytis cinerea & Penicillium-type & Fungi & Discolored & Healthy \\
\hline \multicolumn{7}{|l|}{$2014-15$} \\
\hline Indoors & 14 & 18 & 6 & 38 & 20 & 43 \\
\hline Outdoors & 5 & 2 & 4 & 11 & 21 & 68 \\
\hline$P$ value & $<0.0001$ & $<0.0001$ & 0.0605 & $<0.0001$ & 0.7500 & 0.0005 \\
\hline \multicolumn{7}{|l|}{$2015-16$} \\
\hline Indoors & 4 & 8 & 1 & 14 & 23 & 63 \\
\hline Outdoors & 5 & 0 & 1 & 6 & 20 & 74 \\
\hline$P$ value & 0.3266 & $<0.0001$ & 0.0510 & $<0.0001$ & 0.4598 & 0.0333 \\
\hline
\end{tabular}




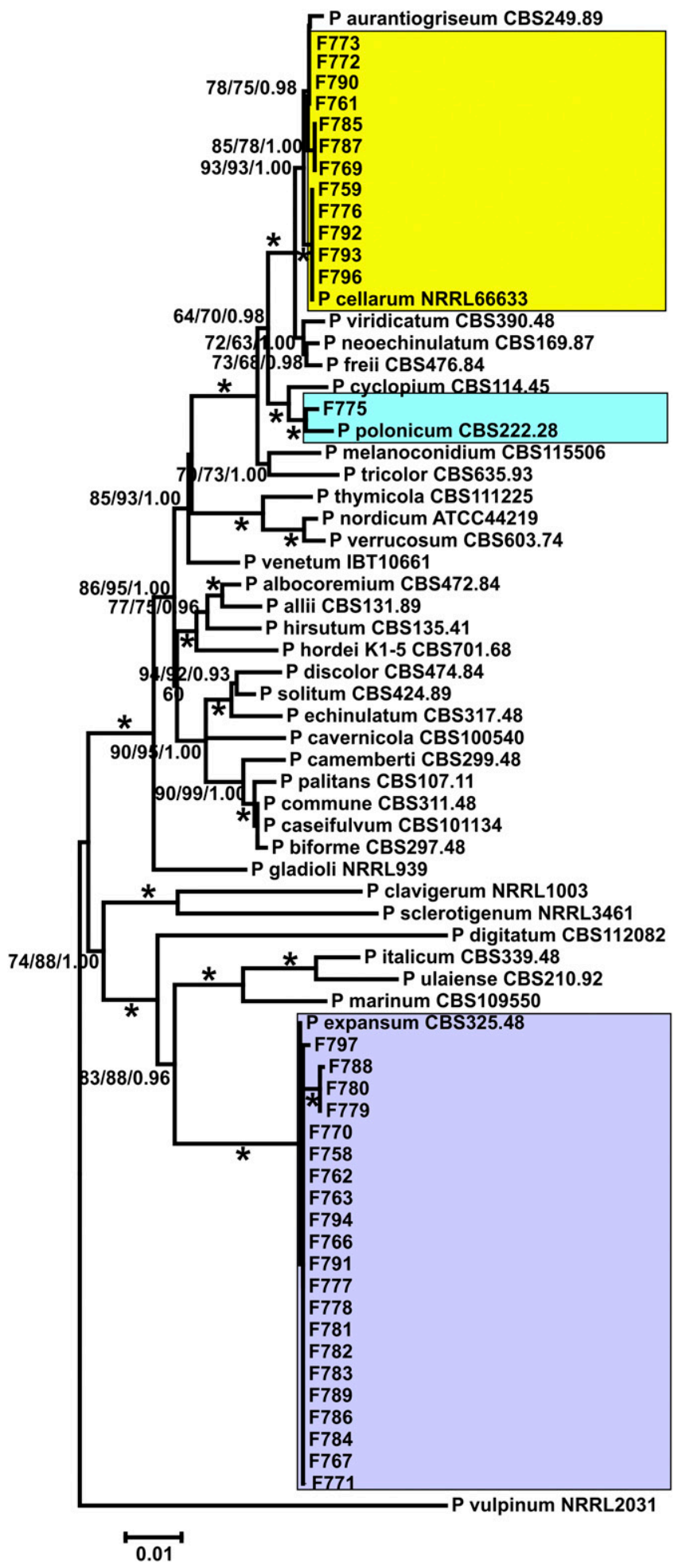

Fig. 2. Phylogenetic relationships among Penicillium spp. and 34 Penicillium isolates (colored boxes) collected from sugar beet roots stored in commercial Idaho piles based on concatenated sequences from the internal transcribed spacer-5.8S, $\beta$-tubulin, RNA polymerase II second largest subunit, and calmodulin DNA regions. The length of the concatenated sequences was 2,100 nucleotides (nt), of which 1,559 nt were conserved, $214 \mathrm{nt}$ were variable but parsimony uninformative, and 327 nt were parsimony informative. Numbers on the nodes of the maximumlikelihood (ML) tree represent the statistical support for ML $(1,000$ replicates, TN93 + G substitution model, left number), maximum parsimony (MP; 1,000 bootstrap replicates, middle number), and Bayesian method (posterior probabilities, right number). NB = no branch. The tree is drawn to scale, with the branch lengths measured in the number of substitutions per site. Asterisks indicate support of $\geq 95 \%$ for $\mathrm{ML}$ and MP and $\geq 0.95$ for the Bayesian method. The tree was rooted to Penicillium vulpinum. Penicillium spp. sequences were obtained from GenBank and the species names are followed by strain designations. mention the Athelia-like fungus in storage piles but additional studies also mention $B$. cinerea and Penicillium spp. as some of the more important fungi in sugar beet storage piles (Bugbee 1982, 1993 Huijbregts et al. 2013; Liebe and Varrelmann 2016; Liebe et al. 2016; Mumford and Wyse 1976; Nihlgård et al. 2009; Strausbaugh et al. 2008b, 2009, 2015; Toda et al. 2012).

In Washington, $P$. vulpinum has been reported to be widespread on commercially stored sugar beet roots (Bugbee 1975). With ambient storage conditions in Washington being similar to those in Idaho, we were not expecting to find $P$. expansum and $P$. cellarum to be the most prevalent Penicillium spp. Sugar beet storage work in the Red River Valley does not mention $P$. expansum but does acknowledge $P$. variabile Sopp (Bugbee 1975). However, the most recent taxonomic revision of the Penicillium spp. by Visagie et al. (2014) does not include $P$. variabile. The current name of $P$. variabile Sopp is considered to be Talaromyces variabilis (Sopp) Samson, Yilmaz, Frizvad \& Seifert. This Talaromyces sp. was only rarely found in the Red River Valley storage system (Bugbee 1975) whereas, in Idaho as part of the current study, T. rugulosus was rarely found.

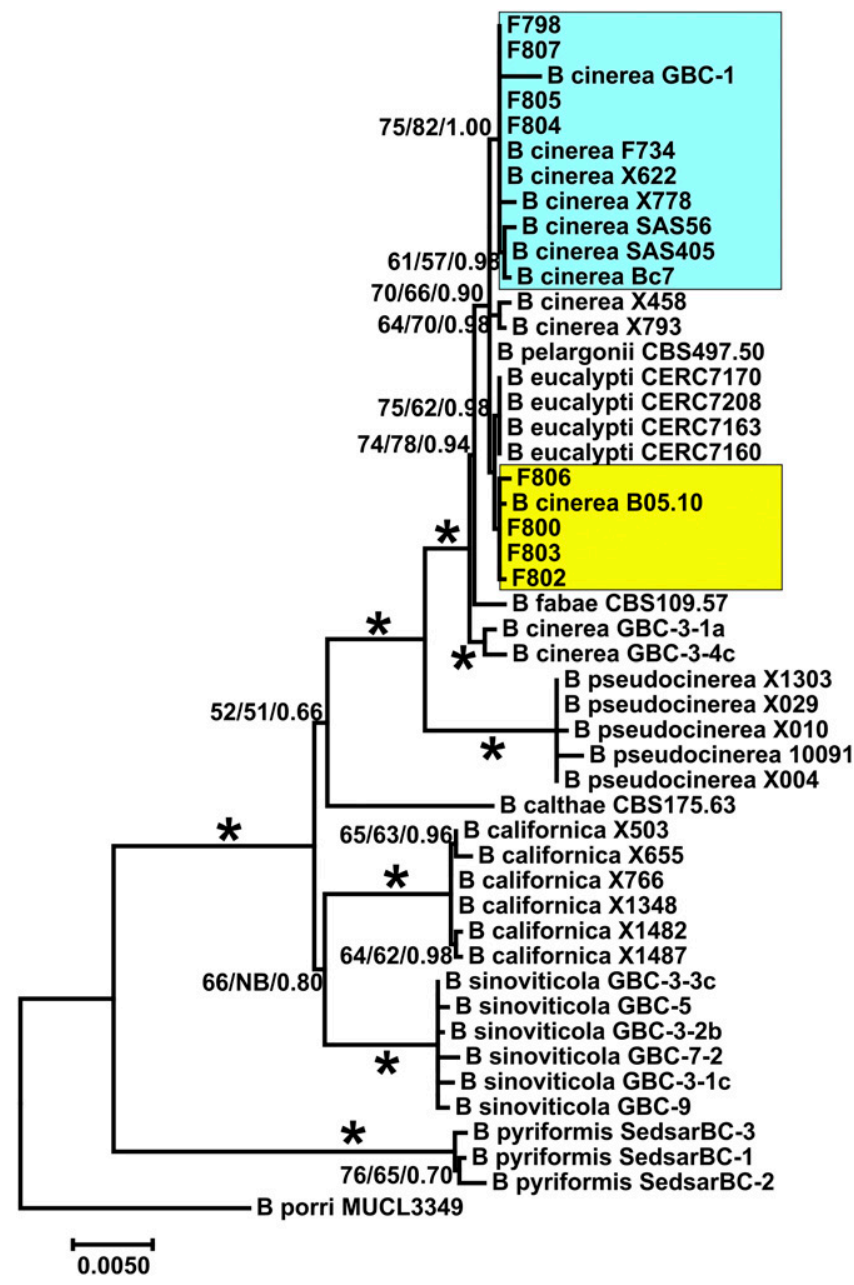

Fig. 3. Phylogenetic relationships among Botrytis spp. and eight Botrytis isolates (colored boxes) collected from sugar beet roots stored in commercial Idaho piles based on concatenated sequences from the internal transcribed spacer-5.8S, RNA polymerase II second largest subunit, glyceraldehyde-3-phosphate dehydrogenase, and heat-shock protein 60 DNA regions. The length of the concatenated sequences was 3,198 nucleotides (nt), of which 2,895 nt were conserved, $100 \mathrm{nt}$ were variable but parsimony uninformative, and $203 \mathrm{nt}$ were parsimony informative. Numbers on the nodes of the maximum-likelihood (ML) tree represent the statistical support for ML (1,000 replicates, T92 + G substitution model, left number), maximum parsimony (MP; 1,000 bootstrap replicates, middle number), and Bayesian method (posterior probabilities, right number). NB $=$ no branch. The tree is drawn to scale, with the branch lengths measured in the number of substitutions per site. Asterisks indicate support of $\geq 95 \%$ for $\mathrm{ML}$ and MP and $\geq 0.95$ for the Bayesian method. The tree was rooted to Botrytis porri. The Botrytis spp. sequences were obtained from GenBank and the species names are followed by strain designations. 
The fungal species documented from rot in stored sugar beet roots in Idaho, Washington, and the Red River Valley in the United States and between various countries can vary (Bugbee 1982, 1993; Christ et al. 2011; Huijbregts et al. 2013; Liebe and Varrelmann 2016; Liebe et al. 2016; Sheikholeslami et al. 1998; Strausbaugh et al. 2015; Uchino 2001). Because field disease problems have been documented to have considerable impact on sugar beet roots in storage, some of the differences noted between studies may have been influenced by disease pressure in the field (Campbell and Klotz 2006; Campbell et al. 2008, 2011; Klotz and Campbell 2009; Smith and Ruppel 1971; Strausbaugh et al. 2008a,b, 2011). One major disease problem in Idaho that was not present prior to 1992 is rhizomania caused by Beet necrotic yellow vein virus (BNYVV) (Neher and Gallian 2014). In Idaho, BNYVV was considered to have spread

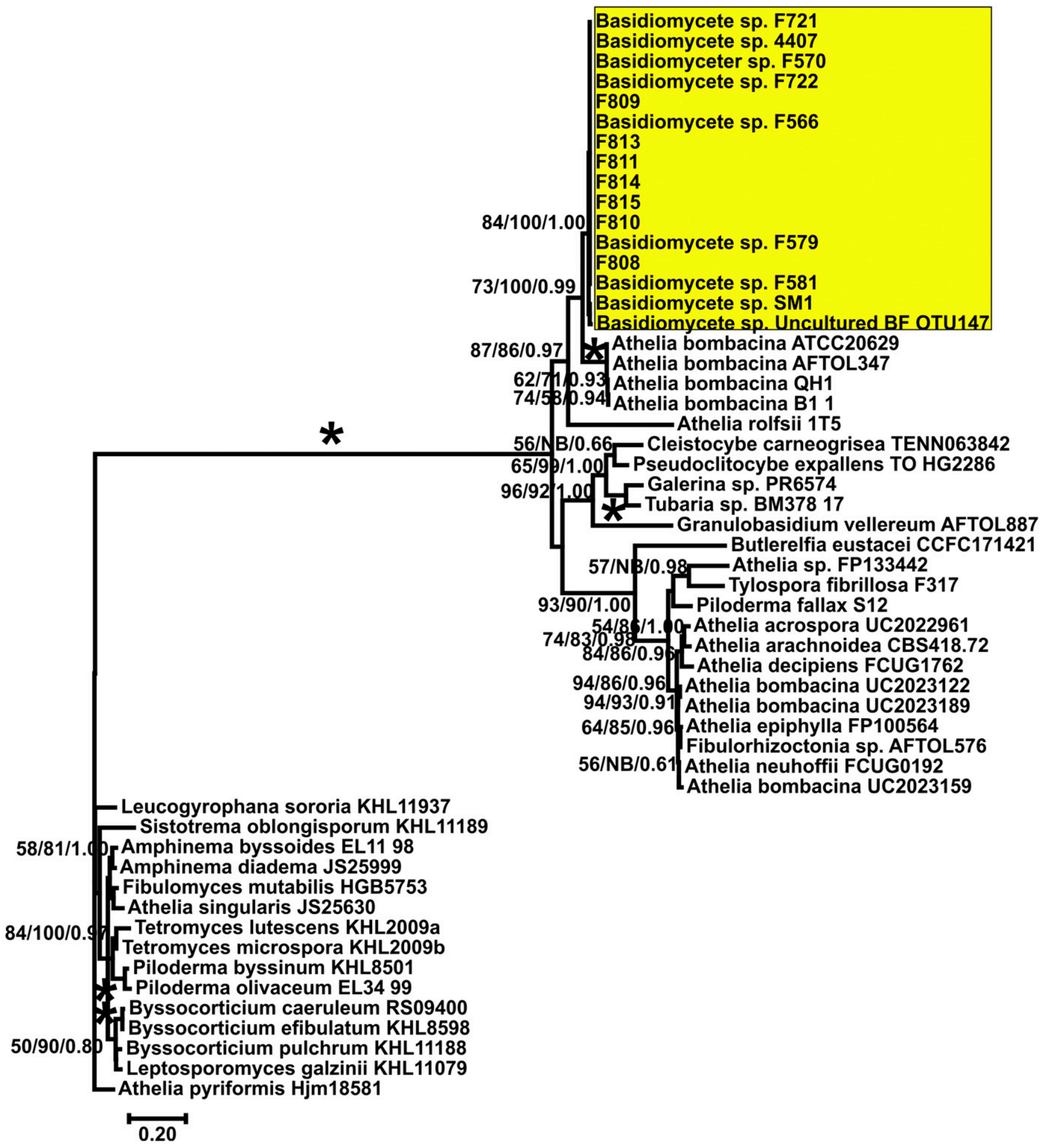

Fig. 4. Phylogenetic relationships among Basidiomycete spp. and seven Athelia-like sp. isolates (yellow box) collected from sugar beet roots stored in commercial Idaho piles based on sequences from the internal transcribed spacer-5.8S DNA region. The length of the sequences was 772 nucleotides (nt), of which $172 \mathrm{nt}$ were conserved, $82 \mathrm{nt}$ were variable but parsimony uninformative, and $518 \mathrm{nt}$ were parsimony informative. Numbers on the nodes of the maximum-likelihood (ML) tree represent the statistical support for ML (1,000 replicates, TN93 + G substitution model, left number), maximum parsimony (MP; 1,000 bootstrap replicates, middle number), and Bayesian method (posterior probabilities, right number). $\mathrm{NB}=$ no branch. The tree is drawn to scale, with the branch lengths measured in the number of substitutions per site. Asterisks indicate support of $\geq 95 \%$ for $\mathrm{ML}$ and $\mathrm{MP}$ and $\geq 0.95$ for the Bayesian method. The tree was rooted to Athelia pyriformis. The Basidiomycete spp. sequences were obtained from GenBank and the species names are followed by strain designations. 
to all commercial fields by 1996 (Neher and Gallian 2014). A 2009 Idaho storage study investigating the influence of BNYVV on stored roots documented a correlation between the Athelia-like fungus and surface rot and sucrose loss but also showed that the fungus was correlated with the rhizomania rating in 1 of 2 years (Strausbaugh et al. 2009). Thus, the presence of rhizomania could have altered the findings in the present study when compared with studies conducted prior to the introduction of BNYVV. Other major disease

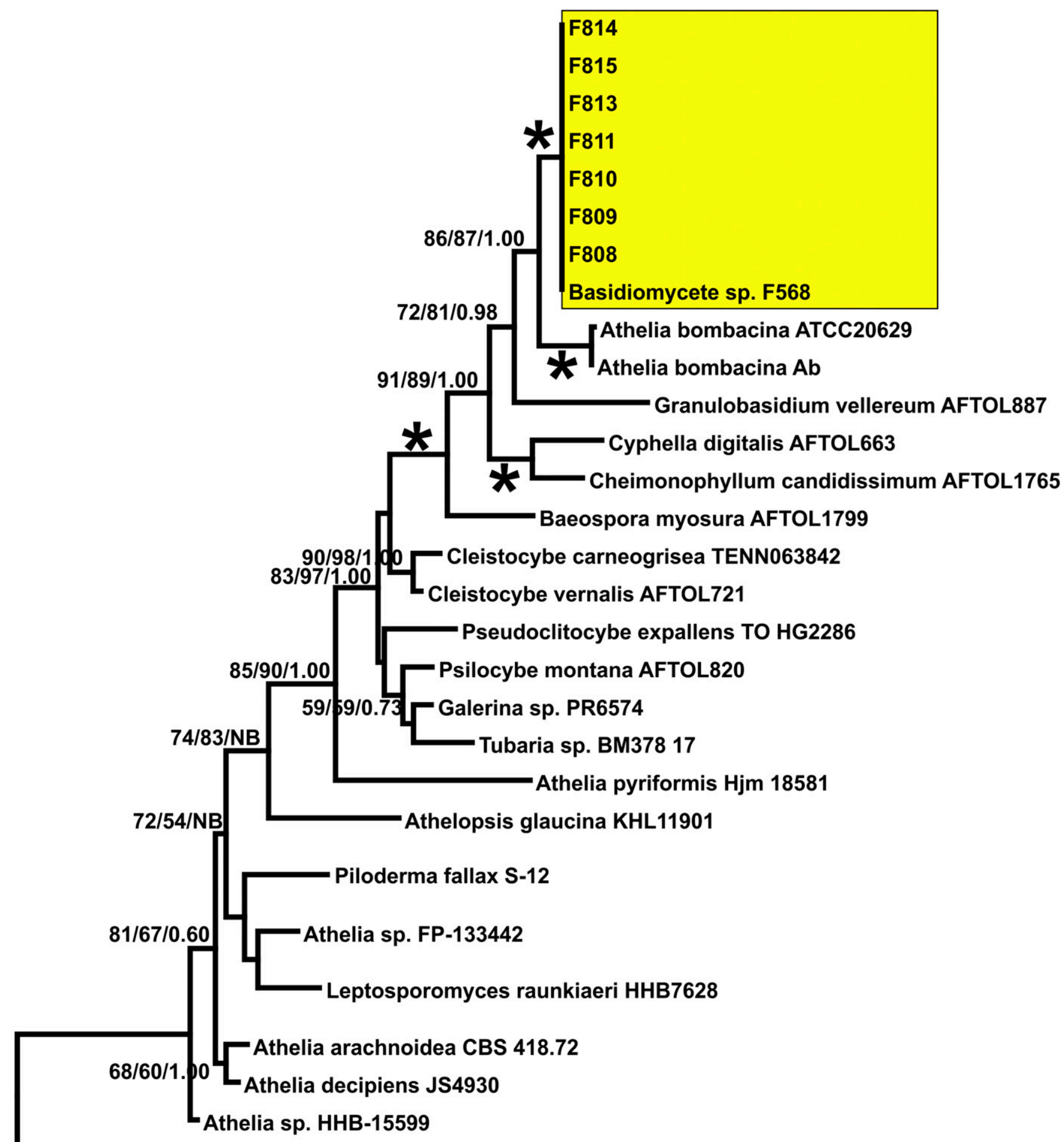

Athelia epiphylla FP-100564

0.050

Fig. 5. Phylogenetic relationships among Basidiomycete spp. and seven Athelia-like sp. isolates (yellow box) collected from sugar beet roots stored in commercial Idaho piles based on sequences from the $28 \mathrm{~S}$ ribosomal RNA DNA region. The length of the sequences was 1,295 nucleotides (nt), of which $873 \mathrm{nt}$ were conserved, $232 \mathrm{nt}$ were variable but parsimony uninformative, and $190 \mathrm{nt}$ were parsimony informative. Numbers on the nodes of the maximum-likelihood (ML) tree represent the statistical support for ML (1,000 replicates, TN93 + G substitution model, left number), maximum parsimony (MP; 1,000 bootstrap replicates, middle number), and Bayesian method (posterior probabilities, right number). NB = no branch. The tree is drawn to scale, with the branch lengths measured in the number of substitutions per site. Asterisks indicate support of $\geq 95 \%$ for $\mathrm{ML}$ and MP and $\geq 0.95$ for the Bayesian method. The tree was rooted to Athelia epiphylla. The Basidiomycete spp. sequences were obtained from GenBank and the species names are followed by strain designations. 
problems such as Aphanomyces root rot, beet curly top, and Cercospora leaf spot that vary in importance annually and between Idaho and the Red River Valley and other areas may have also influenced results between older literature and more recent studies (Campbell and Klotz 2006; Smith and Ruppel 1971; Strausbaugh et al. 2008a). Another factor that might lead to differences between studies was the difference in timing when samplings were conducted (Uchino 2001).

Isolates of the Athelia-like sp. have been shown to be pathogenic in the current study and previous investigations (Strausbaugh et al. 2009,2015 ) but confirming the presence of the fungus through tissue isolations has been problematic in all of the studies. In all of the studies, the primary contaminants in the isolations were Penicillium spp. When the Athelia-like sp. was observed on sugar beet roots in the piles, the isolation percentage ranged from 45 to $86 \%$ in both years. In the pathogenicity tests, the tissue isolations were only $50 \%$ successful in both years. However, the inoculation sites for the noninoculated controls and those for the nonpathogenic T. rugulosus did not become contaminated even though the root surface had not been sterilized prior to inoculation. As noted previously, the lesions created by the Athelia-like sp. appear to facilitate the Penicillium spp. to also become established in the colonized root tissue (Strausbaugh et al. 2009, 2015). Penicillium spp. typically need a wound to become established in sugar beet root tissue (Fugate and Campbell 2009). Even though Penicillium spp. were frequently associated with the Athelia-like inoculations, the lesion size for the Athelia-like isolates was usually smaller than when Penicillium spp. had been inoculated individually. When grouped by fungal type for comparison, the Penicillium spp. were more virulent than the Athelia-like fungus. A previous investigation has shown that $P$. vulpinum could be antagonistic to B. cinerea when coinoculated (Bugbee 1982). In the current study, the Athelia-like lesions were similar in size with and without contamination. However, the current study did not directly investigate

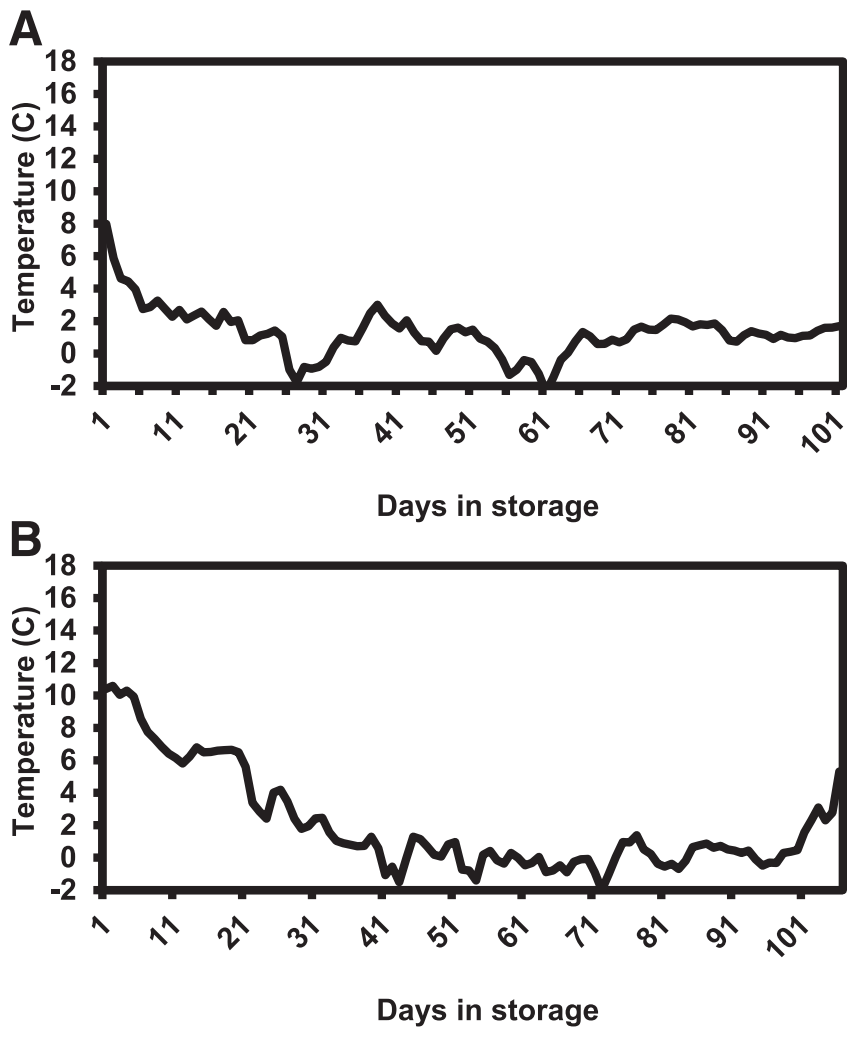

Fig. 6. Average daily temperature $\left({ }^{\circ} \mathrm{C}\right)$ from sensors placed in with roots during storage for pathogenicity tests in commercial sugar beet indoor storage facility in Paul, ID with A, 2015 roots from 2 November 2015 to 10 February 2016 (101 days in storage) and B, 2016 roots from 27 October 2016 to 9 February 2017 (106 days). whether Penicillium spp. could have an influence on the growth of the Athelia-like fungus.

Managing sugar beet storage rots in commercial storage has been attempted through options such as placing only disease- and stressfree roots in piles, limiting damage to roots going into storage, using rot-resistant cultivars, and using physical and chemical control methods (Akeson et al. 1979; Bernhardson 2009; Bugbee 1982, 1993; Bugbee and Cole 1979; Miles et al. 1977; Peterson et al. 1980, 1984; Strausbaugh and Eujayl 2018; Strausbaugh et al. 2015; Wu et al. 1970). In commercial U.S. sugar beet piles, the focus for controlling storage rots has been primarily through physical control methods, although roots held for seed production by research geneticists and private companies may also receive fungicide applications (Bernhardson 2009; Bugbee 1993; Peterson et al. 1980, 1984; Strausbaugh et al. 2015). The use of these physical control methods at the outdoor OVP1 and OVP2 piles was very effective in both years at limiting fungal growth to $2 \%$ or less of the root surface after more than 120 days of storage under ambient conditions. These two piles also had the highest elevation $(1,324$ to $1,325 \mathrm{~m})$ of all the piles; therefore, they may have had cooler air to maintain pile temperature, because ambient air was used to cool all the piles. The lowest-elevation pile was OVP5 $(1,168 \mathrm{~m})$, which also ranked first for the most surface fungal growth in both years among the outdoor piles. In fact, the performance of OVP5 was poor enough that it

Table 4. Pathogenicity test with 30 fungal storage rot isolates inoculated individually and compared versus a noninoculated check using roots of the commercial sugar beet cultivar B-7 grown in Idaho and harvested in 2015 and 2016

\begin{tabular}{|c|c|c|c|}
\hline \multirow[b]{2}{*}{ Fungal isolate $^{\mathrm{z}}$} & \multirow[b]{2}{*}{ Species } & \multicolumn{2}{|c|}{ Fungal root rot (mm) } \\
\hline & & 2015 & 2016 \\
\hline F800 & Botrytis cinerea & $68 \mathrm{~b}$ & $66 \mathrm{a}$ \\
\hline F804 & B. cinerea & $77 \mathrm{a}$ & $58 \mathrm{~b}$ \\
\hline F802 & B. cinerea & $62 \mathrm{~b}$ & $58 \mathrm{~b}$ \\
\hline F803 & B. cinerea & $66 \mathrm{~b}$ & $57 \mathrm{~b}$ \\
\hline F733 & B. cinerea & $51 \mathrm{c}$ & $47 \mathrm{c}$ \\
\hline F731 & Penicillium expansum & $33 \mathrm{~d}-\mathrm{g}$ & $41 \mathrm{~d}$ \\
\hline F763 & P. expansum & $34 \mathrm{de}$ & $40 \mathrm{de}$ \\
\hline F797 & P. expansum & $36 \mathrm{~d}$ & $40 \mathrm{de}$ \\
\hline F794 & P. expansum & $33 \mathrm{~d}-\mathrm{g}$ & $39 \mathrm{de}$ \\
\hline F775 & P. polonicum & $34 \mathrm{~d}-\mathrm{f}$ & $39 \mathrm{de}$ \\
\hline F770 & P. expansum & $28 \mathrm{e}-\mathrm{j}$ & $38 \mathrm{~d}-\mathrm{f}$ \\
\hline F791 & P. expansum & $28 \mathrm{f}-\mathrm{k}$ & $36 \mathrm{~d}-\mathrm{g}$ \\
\hline F766 & P. expansum & $30 \mathrm{~d}-\mathrm{i}$ & $36 \mathrm{e}-\mathrm{h}$ \\
\hline F786 & P. expansum & $31 \mathrm{~d}-\mathrm{h}$ & $35 \mathrm{e}-\mathrm{h}$ \\
\hline F727 & P. cellarum & $31 \mathrm{~d}-\mathrm{h}$ & $33 \mathrm{f}-\mathrm{i}$ \\
\hline F792 & P. cellarum & $25 \mathrm{~h}-\mathrm{m}$ & $32 \mathrm{~g}-\mathrm{j}$ \\
\hline F793 & P. cellarum & $27 \mathrm{~g}-1$ & $32 \mathrm{~g}-\mathrm{j}$ \\
\hline F796 & P. cellarum & $24 \mathrm{i}-\mathrm{n}$ & $31 \mathrm{~h}-\mathrm{k}$ \\
\hline F776 & P. cellarum & $30 \mathrm{~d}-\mathrm{h}$ & $30 \mathrm{i}-\mathrm{k}$ \\
\hline F730 & P. cellarum & $26 \mathrm{~h}-\mathrm{m}$ & $29 \mathrm{i}-1$ \\
\hline F785 & P. cellarum & $25 \mathrm{~h}-\mathrm{m}$ & $29 \mathrm{i}-1$ \\
\hline F787 & P. cellarum & $23 \mathrm{j}-\mathrm{n}$ & $28 \mathrm{j}-\mathrm{m}$ \\
\hline F773 & P. cellarum & $21 \mathrm{k}-\mathrm{n}$ & $26 \mathrm{k}-\mathrm{m}$ \\
\hline F772 & P. cellarum & $23 \mathrm{j}-\mathrm{n}$ & $26 \mathrm{k}-\mathrm{m}$ \\
\hline F808 & Athelia-like sp. & $20 \mathrm{mn}$ & $241-n$ \\
\hline F813 & Athelia-like sp. & $23 \mathrm{j}-\mathrm{n}$ & $23 \mathrm{mn}$ \\
\hline F809 & Athelia-like sp. & $22 \mathrm{j}-\mathrm{n}$ & $21 n$ \\
\hline F814 & Athelia-like sp. & $211-n$ & $21 \mathrm{n}$ \\
\hline F722 & Athelia-like sp. & $18 \mathrm{n}$ & $20 n$ \\
\hline Check & Noninoculated check & 0 o & 0 o \\
\hline F774 & Talaromyces rugulosus & $0 \mathrm{o}$ & $0 \mathrm{o}$ \\
\hline$P$ value & $\ldots$ & $<0.0001$ & $<0.0001$ \\
\hline
\end{tabular}

${ }^{\mathrm{z}}$ The Athelia-like sp. is a basidiomycete described previously (Toda et al. 2012). Fungal root rot $=$ internal root rot measurements from two studies conducted in different years in a commercial indoor sugar beet storage building and arranged in a randomized complete block design with six replicates. $P$ value was the probability associated with the $F$ value. Means followed by the same letter within a column did not differ based on least square means $(\alpha=0.05)$. 
was relocated after 2015 and oriented north-south to better catch the wind for cooling prior to being tarped. Based on the OVP1 and OVP2 piles, physical control methods have been shown to be effective at limiting fungal growth in piles tarped and cooled with ambient air even with sugar beet roots held for more than 120 days. Thus, when siting future vent piles for long-term sugar beet storage, pile orientation and finding sites with access to cooler air could be taken into consideration. The OVP1 and OVP2 piles were also considerably better at controlling fungal growth than the two indoor piles. Even if you could find a better location for the indoor piles, the buildings cannot be moved and the infrastructure for the vent piles is considerably cheaper to establish than the large buildings required for indoor piles. As long as the sugar company can continue to find suitable locations for vent piles, they will potentially not need additional control measures for sugar beet fungal storage rots in those areas. The indoor buildings and long-term vent piles in locations prone to storage rots could potentially benefit from fungicide applications but none are labeled for this purpose at this time (Strausbaugh et al. 2015).

\section{Acknowledgments}

We thank the Amalgamated Sugar Co., LLC, Beet Sugar Development Foundation, and Snake River sugar beet growers for supporting our research work; and J. Reed, D. Kenney, and T. Keeth for their technical support efforts.

\section{Literature Cited}

Akeson, W. R., Yun, Y. M., and Sullivan, E. F. 1979. Effect of chemicals on sucrose loss in sugarbeets during storage. J. Am. Soc. Sugar Beet Technol. 20:255-268.

Altschul, S. F., Madden, T. L., Schäffer, A. A., Zhang, J., Zhang, Z., Miller, W., and Lipman, D. J. 1997. Gapped BLAST and PSI-BLAST: A new generation of protein database search programs. Nucleic Acids Res. 25:3389-3402.

Barr, C., Guinn, E. M., and Rice, R. A. 1940. A preliminary report on the effect of temperature and beet conditions on respiration and loss of sugar from beets in storage. Proc. Am. Soc. Sugar Beet Technol. 2:52-65.

Bernhardson, D. 2009. Sugarbeet storage techniques developed. Int. Sugar J. 111: 628-631.

Bosch, U., and Mirocha, C. J. 1992. Toxin production by Fusarium species from sugar beets and natural occurrence of zearalenone in beets and beet fibers. Appl. Environ. Microbiol. 58:3233-3239.

Bugbee, W. M. 1975. Penicillium claviforme and Penicillium variable: Pathogens of stored sugar beets. Phytopathology 65:926-927.

Bugbee, W. M. 1982. Storage rot of sugar beet. Plant Dis. 66:871-873.

Bugbee, W. M. 1993. Storage. Pages 551-570 in: The Sugar Beet Crop: Science into Practice. D. A. Cooke and R. K. Scott, eds. Chapman and Hall, London.

Bugbee, W. M., and Cole, D. F. 1976. Sugarbeet storage rot in the Red River Valley 1974-75. J. Am. Soc. Sugar Beet Technol. 19:19-24.

Bugbee, W. M., and Cole, D. F. 1979. Comparison of thiabendazole and genetic resistance for control of sugar beet storage rot. Phytopathology 69:1230-1232.

Bugbee, W. M., and Nielsen, G. E. 1978. Penicillium cyclopium and Penicillium funiculosum as sugarbeet storage rot pathogens. Plant Dis. Rep. 62:953-954.

Campbell, L. G., Fugate, K. K., and Niehaus, W. S. 2011. Fusarium yellows affects postharvest respiration rate, sucrose concentration, and invert sugar in sugarbeet. J. Sugar Beet Res. 48:17-39.

Campbell, L. G., and Klotz, K. L. 2006. Postharvest storage losses associated with Aphanomyces root rot in sugarbeet. J. Sugar Beet Res. 43:113-127.

Campbell, L. G., Klotz, K. L., and Smith, L. J. 2008. Postharvest storage losses associated with rhizomania in sugar beet. Plant Dis. 92:575-580.

Campbell, L. G., Windels, C. E., Fugate, K. K., and Brantner, J. R. 2014. Postharvest losses associated with severity of Rhizoctonia crown and root rot of sugarbeet at harvest. J. Sugar Beet Res. 51:31-51.

Christ, D. S., Märländer, B., and Varrelmann, M. 2011. Characterization and mycotoxigenic potential of Fusarium species in freshly harvested and stored sugar beet in Europe. Phytopathology 101:1330-1337.

Delp, B. R., Stowell, L. J., and Marois, J. J. 1986. Evaluation of field sampling techniques for estimation of disease incidence. Phytopathology 76:1299-1305.

Fugate, K., and Campbell, L. 2009. Postharvest deterioration of sugar beet. Pages 92-94 in: Compendium of Beet Diseases and Pests, 2nd ed. R. M. Harveson, L. E. Hanson, and G. L. Hein, eds. American Phytopathological Society, St. Paul, MN.

Hall, T. 1999. BioEdit: A user-friendly biological science sequence alignment editor and analysis program for Windows 95/98/NT. Nucleic Acids Symp. Ser. 41:95-98

Halloin, J. M., and Roberts, D. L. 1995. Temperature as a determining factor in the storage rot of sugarbeet caused by Aspergillus fumigatus. J. Sugar Beet Res. 32: 59-67.

Hansen, C. M. 1949. The storage of sugar beets. Agric. Eng. 30:377-378.

Hong, S. B., Cho, H. S., Shin, H. D., Frisvad, J. C., and Samson, R. A. 2006. Novel Neosartorya species isolated from soil in Korea. Int. J. Syst. Evol. Microbiol. $56: 477-486$
Huff, J. 2013. The hidden cost of beet storage. Sugarbeet Harvest Issue:3-4

Huijbregts, T., Legrand, G., Hoffman, C., Olsson, R., and Olsson, Å. 2013. Long term storage of sugar beet in North-West Europe. Coordination Beet Research International (COBRI). Rep. No. 1-2013.

Isaksson, A. 1942. A Botrytis form causing storage rot in sugar beets. Proc. Am. Soc. Sugar Beet Technol. 3:423-430.

Kenter, C., Hoffman, C., and Märländer, B. 2006. Sugarbeet as raw materialAdvanced storage management to gain good processing quality. Sugar Ind. 131:706-720.

Klotz, K. L., and Campbell, L. G. 2009. Effects of Aphanomyces root rot on carbohydrate impurities and sucrose extractability in postharvest sugar beet. Plant Dis. 93:94-99.

Kumar, S., Stecher, G., and Tamura, K. 2016. MEGA7: Molecular evolutionary genetics analysis Version 7.0 for bigger datasets. Mol. Biol. Evol. 33: 1870-1874.

Larkin, M. A., Blackshields, G., Brown, N. P., Chenna, R., McGettigan, P. A., McWilliam, H., Valentin, F., Wallace, I. M., Wilm, A., Lopez, R., Thompson, J. D., Gibson, T. J., and Higgins, D. G. 2007. Clustal W and Clustal X version 2.0. Bioinformatics 23:2947-2948.

Liebe, S., and Varrelmann, M. 2016. Effect of environment and sugar beet genotype on root rot development and pathogen profile during storage. Phytopathology 106:65-75.

Liebe, S., Wibberg, D., Winkler, A., Pühler, A., Schlüter, A., and Varrelmann, M. 2016. Taxonomic analysis of the microbial community in stored sugar beets using high-throughput sequencing of different marker genes. FEMS Microbiol. Ecol. 92:fiw004.

Miles, W. G., Shaker, F. M., Nielson, A. K., and Ames, R. R. 1977. A laboratory study on the ability of fungicides to control beet rotting fungi. J. Am. Soc. Sugar Beet Technol. 19:288-293.

Mumford, D. L., and Wyse, R. E. 1976. Effect of fungus infection on respiration and reducing sugar accumulation of sugarbeet roots and use of fungicides to reduce infection. J. Am. Soc. Sugar Beet Technol. 19:157-162.

Neher, O. T., and Gallian, J. J. 2014. Rhizomania on sugar beet-Importance, identification, and control. Pac. NW Ext. Publ. PNW 657. University of Idaho, Moscow.

Nelson, P. E., Toussoun, T. A., and Marasas, W. F. O. 1983. Fusarium species, an Illustrated Manual for Identification. The Pennsylvania State University Press, University Park.

Nihlgård, M., Levall, M., Jonsson, R., Lennefors, B.-L., Larson, R., and Steinrucken, G. 2009. Storage diseases-Assessment and implications for breeding. J. Sugar Beet Res. 46:91-92.

Oksanen, J., Blanchet, F. G., Friendly, M., Kindt, R., Legendre, P., McGlinn, D. Minchin, P. R., O’Hara, R. B., Simpson, G. L., Solymos, P., Stevens, M. H. M., Szoecs, E., and Wagner, H. 2017. Vegan: Community ecology package. R package version 2.4-4. https://cran.r-project.org

Peterson, C. L., Hall, M. C., and Traveller, D. J. 1984. Sugarbeet storage experiments. Pap. Am. Soc. Agric. Eng. No. 84-4040.

Peterson, C. L., Traveller, D. J., and Hall, M. C. 1980. Loss of sucrose during controlled and conventional storage. J. Am. Soc. Sugar Beet Technol. 20: 517-530.

Rambaut, A. 2016. Tree Figure Drawing Tool. Institute of Evolutionary Biology, University of Edinburgh, Edinburgh, UK.

R Core Team. 2017. R: A Language and Environment for Statistical Computing. Online publication. R Foundation for Statistical Computing, Vienna. https:// www.R-project.org/

Ronquist, F., and Huelsenbeck, J. P. 2003. MrBayes 3: Bayesian phylogenetic inference under mixed models. Bioinformatics 19:1572-1574.

Sheikholeslami, M., Hedjaroude, G. A., and Okhovat, M. 1998. Fungi causing postharvest decay of sugar beet root in Kermanshah. Iran. J. Plant Pathol. 34: 84-91.

Smith, G. A., and Ruppel, E. G. 1971. Cercospora leaf spot as a predisposing factor in storage rot of sugar beet roots. Phytopathology 61:1485-1487.

Staats, M., van Baarlen, P., and van Kan, J. A. L. 2005. Molecular phylogeny of the plant pathogenic genus Botrytis and the evolution of host specificity. Mol. Biol. Evol. 22:333-346.

Strausbaugh, C. A., and Dugan, F. 2017. A novel Penicillium sp. causes rot in stored sugar beet roots in Idaho. Plant Dis. 101:1781-1787.

Strausbaugh, C. A., and Eujayl, I. A. 2018. Influence of Beet necrotic yellow vein virus and freezing temperatures on sugar beet roots in storage. Plant Dis. 102 932-937.

Strausbaugh, C. A., Eujayl, I. A., and Foote, P. 2013. Selection for resistance to the Rhizoctonia-bacterial root rot complex in sugar beet. Plant Dis. 97:93-100.

Strausbaugh, C. A., Eujayl, I. A., Rearick, E., Foote, P., and Elison, D. 2009. Sugar beet cultivar evaluation for storability and rhizomania resistance. Plant Dis. 93 632-638

Strausbaugh, C. A., Neher, O., Rearick, E., and Eujayl, I. A. 2015. Influence of harvest timing, fungicides, and Beet necrotic yellow vein virus on sugar beet storage. Plant Dis. 99:1296-1309.

Strausbaugh, C. A., Rearick, E., and Camp, S. 2008a. Influence of curly top and Poncho Beta on storability of sugarbeet. J. Sugar Beet Res. 45:31-47.

Strausbaugh, C. A., Rearick, E., Camp, S., Gallian, J. J., and Dyer, A. T. 2008b. Influence of Beet necrotic yellow vein virus on sugar beet storability. Plan Dis. 92:581-587. 
Strausbaugh, C. A., Rearick, E., Eujayl, I. A., and Foote, P. 2011. Influence of Rhizoctonia-bacterial root rot complex on storability of sugarbeet. J. Sugar Beet Res. 48:155-180.

Swofford, D. L. 2002. PAUP*. Phylogenetic Analysis Using Parsimony (* and other methods), Vol. 4. Sinauer Associates, Sunderland, MA.

Toda, T., Strausbaugh, C. A., Rodriquez-Carres, M., and Cubeta, M. A. 2012. Characterization of Basidiomycete fungus from stored sugar beet roots. Mycologia 104:70-78.

Uchino, H. 2001. Studies on storage rot in sugar beet (Beta vulgaris). Mem. Grad. Sch. Agric. Hokkaido Univ. 23:319-401.

Van Driessche, R. 2012. Michigan sugar company “Ten years of progress". Sugar Prod. Mag. March 2012:21.
Van Eerd, L. L., Congreves, K. A., and Zandstra, J. W. 2012. Sugar beet (Beta vulgaris L.) storage quality in large outdoor piles is impacted by pile management but not by nitrogen fertilizer or cultivar. Can. J. Plant Sci. 92:129-139.

Visagie, C. M., Houbraken, J., Frisvad, J. C., Hong, S.-B., Klaassen, C. H. W., Perrone G., Seifert, K. A., Varga, J., Yaguchi, T., and Samson, R. A. 2014. Identification and nomenclature of the genus Penicillium. Stud. Mycol. 78:343-371.

Wu, M. T., Singh, B., Theurer, J. C., Olson, L. E., and Salunkhe, D. K. 1970 Control of sucrose loss in sugarbeet during storage by chemicals and modified atmosphere and certain associated physiological changes. J. Am. Soc. Sugar Beet Technol. 16:117-127.

Wyse, R. 1978. Effect of low and fluctuating temperatures on storage life of sugarbeets. J. Am. Soc. Sugar Beet Technol. 20:33-42. 